\title{
The Effect of Teacher's Pedagogical Content Knowledge on Learning Outcomes with Quality Mediator Student Learning Process (A Perceptional Study of Grade XI Students at SMAN in Tasikmalya City)
}

\author{
Nita Marlina \\ Economics Education Department Student, Kuningan University \\ \{nithamarlina.nm@gmail.com\}
}

\begin{abstract}
This research aims to determine the effect of teacher 'Pedagogical Content Knowledge competence on learning outcomes with the Mediator of the Quality of Student Learning Process at SMAN in Tasikmalaya City in economic subjects. The method used in this research is explanatory survey method with questionnaire data collection techniques scale five categories of labels. The population in the study were students of class XI SMAN Kota Tasikmalaya and the samples were taken through Proportionate Random Sampling. The data processing technique used is mediation regression. This technique is used to determine the direct and indirect relationship of exogenous variables to endogenous variables. The results of this research indicate teacher Pedagogical Content Knowledge has a positive effect on student learning outcomes. This means that the higher the competency level of the teacher's Pedagogical Content Knowledge, it will improve student learning outcomes. As well as showing the quality of the learning process mediates
\end{abstract}

Keywords: Pedagogical Content Knowledge; Quality of Learning Process; learning outcomes

\section{Introduction}

Education is a means to improve the quality of human resources that can be obtained through formal and non-formal institutions. The desired quality of education in Indonesia is a change for the better, because in Law no. 20 of 2003 chapter II (two) article 3 on the national education system states that "National education functions to develop capabilities and shape the character and civilization of a nation with dignity in the framework of educating the nation's life. Today, the position of education in life is very important, because education is the main asset in creating quality human beings. Quality human resources (HR) is an important asset for the progress of a nation. Besides other factors such as natural resources, infrastructure and socio-culture as well as capital and political stability. However, human resources have a role to play in managing all components.

Meanwhile, Indonesia's human development index ranking according to the 2013 human development report prepared by the United Nation Development Program (UNDP) is not exactly satisfactory. In the report, it was said that the value of Indonesia's Human Development Index was in the 121 st position out of a total of 187 countries ranked in the 
world. With that ranking, it means that Indonesia is still considered a weak economy country. Competitiveness, let alone competitiveness, is categorized as not yet strong. Indonesia's HDI, namely 0.629 , is still below the world average of 0.694 . Even below the regional figure of 0.683. Indonesia is categorized as a "Medium Development Country" along with 45 other countries. Lost compared to Singapore at 18th, Brunei Darussalam 30th, Malaysia 64th, Thailand 103th and the Philippines 114th [1].

This shows that education in Indonesia is still far from successful. Therefore, it is necessary to make efforts to improve the quality of Indonesian human resources in the midst of competition with the rest of the world through revamping or improving the quality of education. One of the government's efforts to improve the quality of National education is to issue Permen No. 19 of 2005, which contains eight National Education Standards which can be used as a minimum standard for the achievement of the education system in all regions of Indonesia. This national education standard consists of graduate competency standards, content standards, process standards, education standards and educational personnel, facilities and infrastructure standards, management standards, education financing standards, and education assessment standards. However, in reality, the quality of education in general cannot be said to be successful. One indicator of its success can be shown by the results of student learning evaluations, both the evaluation scores in each semester and the National Exam scores. [2] states that "the success of an educational process can be seen from the high and low learning outcomes of students."

Many factors influence the process and student learning outcomes which can be grouped into raw input factors, learning teaching process factors, output factors, environmental input factors, and instrumental input factors. According to [3] that raw input is material for certain learning experiences in the learning teaching process with the hope of changing the output with certain qualifications. The learning process also influences a number of environmental factors, which are input from the environment (environmental input) and a number of instrumental factors (instrumental input) which are deliberately designed and manipulated to support the achievement of the desired output.

The factors that affect student learning outcomes according to Djamarah [3], among others, are grouped into two, namely, internal factors which include physiological factors (physiological conditions and five sensory conditions), and psychological factors (interest, intelligence, talent, motivation). and cognitive abilities); Then second, external factors include environmental factors (natural, socio-cultural) and instrumental factors (curriculum, programs, teachers, facilities and facilities). Learning outcomes achieved by a student are the result of conscious effort and can be measured through evaluation based on certain norms. According to Saraswati [4] that "low student learning outcomes are mainly caused by teacher factors". In this regard, the teacher is one of the keys to success in education. The core of educational activities in the schools is the teaching and learning process where teachers have a very important and dominant role in achieving educational goals. [5] states that "the learning process and student learning outcomes are not only determined by the school, the pattern, structure, and content of the curriculum, but mostly by the competence of teachers who teach and guide them".

In line with Hamalik, [6], based on the results of studies in developing countries, teachers contribute $36 \%$ to student achievement, then management $23 \%$, study time $22 \%$, and physical facilities by $19 \%$. In addition, [7] explains that: Teacher factors and teaching methods are the most important factors in determining the success or failure of student learning. How the teacher's attitude and personality, the level of teacher's knowledge, and how the teacher 
teaches knowledge to their students, also determines how learning outcomes can be achieved by children

Viewing the importance of the position of teachers in improving the quality of education, teachers are also a profession that directly requires the professionalism of an educator to master the ability to teach a concept so that it is not only in the form of material but more on the meaning of knowledge for students. This means, a teacher is not only required to master the content but must also be able to master how to teach the content to students. A teacher should have professional teaching skills so that the knowledge transfer process can be accepted and understood by students. A teacher must have knowledge of students and their characteristics, knowledge of the educational context, knowledge of objectives, values, philosophical and historical knowledge of education, content knowledge, curriculum knowledge and pedagogical knowledge [13]. According to him also, teachers must have knowledge of phenomena which are learning content and knowledge of how to teach this content to students [12].

Teachers not only carry out the function of transfer of knowledge (transfer of knowledge), but also function to instill values and build character of students in a sustainable manner. Pedagogical Content Knowledge (PCK) is a combination of special abilities from content and pedagogical knowledge that are formed over time and a teacher's teaching experience. [11]. PCK has been accepted as an academic construct that links several variables with teachers' basic professional knowledge. The PCK academic construct is an identifier that teaching is not just a transfer of knowledge and skills from teachers to students, but is more complex than that because it includes complex activities and requires various decisions and responses to learners' learning. A good PCK is identical with an effective teacher. However, effective teachers are not born, but are formed through a series of processes and a long time to acquire the skills and knowledge needed to become professional teachers.

[12] in [9] argues that there are 4 types of knowledge that make teachers effective in teaching, namely: 1) General pedagogical knowledge, 2) Content knowledge, 3) Pedagogical content knowledge, 4) Curricular knowledge. These four requirements are important if the quality of the learning process is to be obtained. Likewise, with Hlas, A \& Hildebrandt, S (2010) Competent teachers should have good PCK so that it makes it easier for students to learn. The integration between the two abilities in PCK will increase effectiveness in learning.

The duties and roles of teachers are getting heavier from day to day, along with the development of science and technology. Teachers as the main component in the world of education are required to be able to balance and even go beyond the development of science and technology that develops in society. Through the touch of teachers in schools, it is hoped that they will be able to produce graduates who have high competence and are ready to face life's challenges with full confidence and high confidence. Education in schools must be able to create quality human resources, both scientifically (academically) and mentally.

Given the very central role of teachers in carrying out the learning process and improving student learning outcomes, it can be said that the quality of education, especially in schools, is largely determined by the quality of teacher abilities, although many other factors are related. Thus, if the quality of education at an education level is to be improved, it is better if it starts with improving the quality of a teacher's abilities. 


\section{Method}

The method used in this research is explanatory survey method with questionnaire data collection techniques scale five categories of labels. Data obtained from the results of filling out Likert scale questionnaires by students and documentation study. Data analysis used mediation regression to determine the causal relationship of the three variables by knowing the direct and indirect effects between the PCK Guru variable as an exogenous variable, on the endogenous variable and the mediating variable, namely the quality of the learning process. The population includes 3,381 students and spread over 10 schools with a sampling probability sampling technique of 358 students.

\section{Result and Discussion}

The results of the descriptive statistical processing of the Pedagogical Content Knowledge (PCK) variable of teachers based on the average score, standard deviation and categories are presented in table 1 below:

Table 1. Description of Students' Perceptions of Teacher PCK Competency Variables

\begin{tabular}{|c|c|c|c|c|}
\hline No & Indicator & $\begin{array}{l}\text { Average } \\
\text { Score }\end{array}$ & $\begin{array}{l}\text { Standard } \\
\text { Deviation }\end{array}$ & Category \\
\hline \multicolumn{5}{|c|}{ Pedagogical Dimension of Knowledge } \\
\hline 1 & $\begin{array}{l}\text { The teacher's ability to manage the } \\
\text { class }\end{array}$ & 3,40 & 0,94 & High \\
\hline 2 & $\begin{array}{l}\text { Knowledge of delivery methods and } \\
\text { learning strategies }\end{array}$ & 3,29 & 1,03 & Medium \\
\hline 3 & Knowledge of students & 3,45 & 1,09 & High \\
\hline 4 & $\begin{array}{l}\text { Knowledge of assessment and } \\
\text { evaluation in learning } \\
\text { Total Dimensions of Pedagogical }\end{array}$ & 3,53 & 1,03 & High \\
\hline & $\begin{array}{l}\text { Knowledge } \\
\text { Content Knowledge Dimensions }\end{array}$ & 3,42 & 1,02 & High \\
\hline 5 & $\begin{array}{l}\text { Mastering the content, structure, and } \\
\text { scientific mindset of the lessons } \\
\text { being taught }\end{array}$ & 3,51 & 0,99 & High \\
\hline 6 & $\begin{array}{l}\text { Developing explanations of creative } \\
\text { learning materials }\end{array}$ & 2,72 & 1,26 & Medium \\
\hline 7 & $\begin{array}{l}\text { Ability to analogize the material } \\
\text { discussed }\end{array}$ & 3,30 & 1,10 & Medium \\
\hline 8 & $\begin{array}{l}\text { The perspective of continuous } \\
\text { teacher development by taking } \\
\text { reflective actions }\end{array}$ & 3,25 & 1,02 & Medium \\
\hline 9 & $\begin{array}{l}\text { Ability to choose / take advantage of } \\
\text { technology }\end{array}$ & 3,13 & 1,26 & Medium \\
\hline Tot & Dimension of Content Knowledge & 3,18 & 1,07 & Medium \\
\hline Tota & PCK Teacher Competency & 3,29 & 1,05 & Medium \\
\hline
\end{tabular}

Based on the data in table 1 above, overall students' perceptions of the teacher PCK Competence at SMAN in Tasikmalaya City are in the medium category with an average score of 3.29 and a standard deviation of 1.05. This shows that, teacher PCK Competence at SMAN in Tasikmalaya City is perceived by students is not good enough to support student learning 
outcomes. Based on the descriptive statistical test results that have been described previously, it shows that the average score of teacher PCK competence is 3.29 in the medium category. This means that it has not reached the ideal maximum score (5.00). However, these results indicate empirically the PCK competency can be explained by the indicators above. The lack of good PCK competence for teachers is caused by several things, including: 1) the lack of motivation of teachers to improve their quality, 2) the number of teachers who work outside their working hours to fulfill their daily needs, so that the time to read and write to improve their competence is not sufficient 3 ) the non-functioning of the subject teacher deliberations (MGMP) as an organization that seeks to improve the professionalism of its members.

The results also showed that the Knowledge indicator regarding assessment and evaluation in learning had the highest score, which was 3.53. In sequence followed by indicators of Mastering the content, structure, and scientific mindset of the lessons taught with an average score of 3.51, Knowledge of students with an average score of 3.45, indicators of the ability of teachers to manage the class with an average score 3.40 average, the indicator of the ability to analogize the material discussed with an average score of 3.30, the knowledge indicator about how to deliver and learning strategies with an average score of 3.29 , the perspective indicator for continuous teacher development by taking reflective action with a score an average of 3.25 , the indicator of the ability to choose / utilize technology with an average score of 3.13, and finally the indicator of developing an explanation of learning materials that are taught creatively with an average score of 2.72. These results indicate that the PCK competence of teachers on the Knowledge indicator regarding assessment and evaluation in learning is more dominant than other indicators in this study

These findings indicate that students perceive, teachers in Tasikmalaya State Senior High School as having moderate PCK competency levels. This means that economics teachers in Tasikmalaya must continue to improve their competence. Indicators Developing explanations for learning materials that are guided creatively is an indicator with the lowest average score perceived by students. In this context, teachers are required to be able to master content (learning material) and develop it creatively so that the learning process runs effectively, innovatively and is not boring. Schools and related institutions can facilitate teachers in increasing their competence. One of them with the principal as a leader should be able to further motivate teachers to continue their studies in order to increase professionalism at work, motivate teachers in scientific development that follows the times, provide opportunities for teachers to attend trainings or equip facilities that can help to improve teacher competence.

The learning process quality data were also analyzed using SPSS V. 22. The results of descriptive statistical processing of the quality of the learning process variables based on the average score, standard deviation and categories are presented in table 2 below:

Table 2. Description of Student Perceptions about the Quality of the Learning Process

\begin{tabular}{|c|c|c|c|c|}
\hline No & Indicator & $\begin{array}{l}\text { Average } \\
\text { score }\end{array}$ & $\begin{array}{l}\text { Standard } \\
\text { Deviation }\end{array}$ & Category \\
\hline 1 & Organizing learning & 3,91 & 0,86 & High \\
\hline 2 & Extending of learning & 3,55 & 1,01 & High \\
\hline 3 & $\begin{array}{l}\text { Activities of students in learning } \\
\text { activities }\end{array}$ & 3,85 & 0,88 & High \\
\hline 4 & Teacher and student interactions & 3,87 & 0,96 & High \\
\hline 5 & Learning management & 3,85 & 0,97 & High \\
\hline 6 & $\begin{array}{l}\text { Total Quality of the Learning } \\
\text { Process }\end{array}$ & 3,80 & 0,93 & High \\
\hline
\end{tabular}

Based on the data in table 2 above, overall students' perceptions of the quality of the learning process at the State Senior High School in Tasikmalaya City are in the high category 
with an average score of 3.80 and a standard deviation of 0.93 . This shows that, in general, the quality of the learning process for State Senior High Schools in Tasikmalaya City is good for supporting student learning outcomes. Based on the results of descriptive statistical tests that have been described previously, it shows that the average score of the quality of the learning process is 3.80 , which is in the high category, meaning that it has not reached the ideal maximum score (5.00). However, these results indicate empirically the quality of the learning process can be explained by the indicators above.

The results also showed that the learning organizing indicator had the highest score, which was 3.91. Consequently, it is followed by the teacher and student interaction indicators with an average score of 3.87, the students' activeness in learning activities and learning management with an average score of 3.85 , and finally the learning delivery indicator with an average score of 3.55. These results indicate the quality of the learning process on the indicators of organizing learning is more dominant than other indicators in this study.

These findings indicate that students perceive that the implementation of the learning process at the State Senior High School in Tasikmalaya City has been going well. However, the school, in this case the principal and all components related to the teaching and learning process, must continue to improve the quality of the learning process for the State Senior High Schools in Tasikmalaya City. Because according to, [14] Optimal student learning outcomes depend on student learning process and teacher teaching process. This means that if the learning process is getting better, the learning outcomes will be even better. Based on this, the facilities and infrastructure that can facilitate students in learning according to the subject matter, and supported by the quality of teacher teaching that can facilitate the student learning process, is the best way to improve the learning process in schools. In addition, the principal as the number one person in the school is expected to be able to carry out regular supervision through class visits to observe the learning process directly. From the results of this supervision, it is known that the weaknesses and strengths of the teacher in implementing learning. Furthermore, efforts are made for solutions, coaching, and follow-up to correct deficiencies and maintain excellence in the learning process.

To describe the variable student learning outcomes in Economics, it was obtained from the results of the average UTS and UAS Economics scores for the 2018/2019 academic year. To determine the assessment criteria, the calculation is [(highest score - lowest score): 3], the highest score is 100 and the lowest score is 0 . [(100-0): 3$]=33.33$. The results of 33.33 are the ranges for each class. The following are the assessment criteria for learning outcomes reported in.

Table 3. Learning Outcomes Level

\begin{tabular}{ccccc}
\hline Interval class & Category & Frequency & Percentage (\%) & Average Score \\
\hline $0-33$ & Low & 26 & 7,26 & \\
$34-67$ & Medium & 64 & 17,88 & 70,39 \\
$68-100$ & High & 268 & 74,86 & \\
\hline
\end{tabular}

Based on the table above, it shows that student learning outcomes obtain an average score of 70.39 from a maximum score of 100.The percentage of students who have a score between $0-33$ is $7.26 \%$, who have a value between $34-67$ of $17.88 \%$, and those with a value between $68-100$ of $74.86 \%$. Thus, it can be concluded that in general student learning outcomes in the Economics subject of SMAN in Tasikmalaya City are above the average learning outcomes and are included in the High category.

Based on the analysis of data on student learning outcomes, in general, the UAS and UTS scores of students of SMA Tasikmalaya City are included in the high category. With these 
high scores, it is hope that Senior High School graduates will be able to answer the challenges of the world of work and be able to compete in the era of globalization. The effect of Teacher's Pedagogical Content Knowledge On Student Learning Outcomes. One of the objectives of this research was to determine the effect of PCK on student learning outcomes. The results of these statistical tests can be seen in table 4 .

Table 4. Coefficients regression

\begin{tabular}{|c|c|c|c|c|c|c|}
\hline & & \multicolumn{5}{|c|}{ Coefficients } \\
\hline \multirow{2}{*}{\multicolumn{2}{|c|}{ Model }} & & & Standardized Coefficients & \multirow{2}{*}{$\mathrm{T}$} & \multirow{3}{*}{$\begin{array}{l}\text { Sig. } \\
.000\end{array}$} \\
\hline & & \multirow{2}{*}{$\begin{array}{l}\text { B } \\
88.003 \\
\end{array}$} & \multirow{2}{*}{$\begin{array}{l}\text { Std. Error } \\
5.101\end{array}$} & \multirow[t]{2}{*}{ Beta } & & \\
\hline 1 & (Constant) & & & & 17.253 & \\
\hline & PCK & .144 & .041 & .183 & 3.514 & .000 \\
\hline
\end{tabular}

a. Dependent Variable: HB

Based on the results of statistical calculations with the help of SPSS V. 22 which explains the influence of the variable PCK ability of teachers on student learning outcomes, it can be seen in table 4 and it can be explained that the variable student learning outcomes are positively influenced by the PCK ability of the teacher by 0.183 or $3.35 \%$. $96.65 \%$ is influenced by other variables not explained by the model. The contribution of the PCK ability of teachers did not dominantly affect student learning outcomes. This shows that other variables that are not studied can make a large contribution to learning outcomes by $96.65 \%$. As we know that student learning outcomes as described by [7], are seen in the raw input factors (students) which include internal factors, namely the student's physiological condition such as physical condition, five senses, and so on. Also student psychological factors which include learning motivation, feelings, attitudes, interests, the need for security and conditions due to sociocultural conditions. In addition, other external factors also influence student learning outcomes, including class cleanliness, lighting, learning facilities, learning curricula, school facilities and infrastructure and family factors.

If we look at the magnitude of the influence of the teacher's PCK variable on learning outcomes is 0.183 . This means that if the teacher's PCK increases by 1 standard deviation, the learning outcomes will increase by 0.183 or $3.35 \%$. Based on the results of the research, it shows that the PCK of teachers has a positive effect on learning outcomes in economic subjects. This means that the higher the PCK level of the teacher, the better student learning outcomes will be, and vice versa. If the PCK of the teacher is low, student learning outcomes will be low. The PCK ability of teachers is needed to support student learning outcomes, especially economic learning outcomes that require students to be able to develop high-level cognitive abilities, namely analysis, evaluation, and creation. The development of high-level cognitive abilities is needed so that students not only memorize a concept but also able to apply, analyze, assess and even create a new concept. Because one of the functions of economic subjects is to develop the ability of students to be economical, by getting to know various economic facts and events, understanding concepts and theories and practicing solving economic problems that occur in the community [10].

Viewing from the hypothesis test shows that the PCK ability of teachers has an effect on learning outcomes. This is in line with the theory that refers to the opinion of [13] and Dunkin and Biddle (Sagala, 2011, p. 23) which states that the learning process will run well if educators have two main competencies, namely (1) the competence of the substance of learning materials or mastery subject matter (Content Knowledge) and (2) competency in 
learning methodology and learning strategies (Pedagogical Knowledge). This research is also in accordance with research conducted by Marinkovic (2013) that the results of his research show that the quality of education is determined by teacher competency factors, teacher success is measured by different criteria and measurements including: (1) independent evaluation of the realization of the teacher's role (2) evaluation the role of teachers by students and (3) student motivation as an indicator of the influence of teachers on students. Selfevaluation of teacher competence will develop learning strategies so that student learning outcomes can increase where student learning outcomes are an indicator and a result of teacher competence.

Based on the calculation of the data, a positive correlation coefficient was obtained between the PCK ability of teachers and learning outcomes, namely 0.144 . This means that there is a positive relationship between teachers' PCK abilities and student learning outcomes. The quality of the learning process mediates the effect of economic teacher Pedagogical Content Knowledge (PCK) on student learning outcomes. The path coefficient is calculated by making two structural equations, namely the regression equation which shows the relationship between Pedagogical Content Knowledge (PCK) and the quality of the learning process. From the results of the SPSS V22.0 output below for the first regression equation (1), the following equation is obtained:

Table. 5 Coefficients regression

\begin{tabular}{|c|c|c|c|c|c|c|}
\hline & & \multicolumn{5}{|c|}{ Coefficients } \\
\hline & \multirow[b]{2}{*}{ Model } & \multicolumn{2}{|c|}{ Unstandardized Coefficient } & \multirow{2}{*}{$\begin{array}{c}\text { Standardized Coefficier } \\
\text { Beta } \\
\end{array}$} & & \multirow[b]{2}{*}{$\mathrm{Si}$} \\
\hline & & $\mathrm{B}$ & Std. Error & & & \\
\hline \multirow[t]{2}{*}{1} & (Constant) & 45.865 & 2.649 & & 17.316 & .000 \\
\hline & PCK & .343 & .021 & 651 & 16.168 & .000 \\
\hline
\end{tabular}

a. Dependent Variable: MPP is the quality of learning Process

(1) The quality o Learning Process $=a+a$ PCK $+e 1$

$=45.865+0,651$ PCK

Meanwhile, the second regression equation (2) is obtained as follows:

Table 6. Coefficients regression

\begin{tabular}{|c|c|c|c|c|c|c|}
\hline \multicolumn{7}{|c|}{ Coefficients } \\
\hline & \multirow[b]{2}{*}{ Model } & \multicolumn{2}{|c|}{ Unstandardized Coefficients } & \multirow{2}{*}{$\begin{array}{c}\begin{array}{c}\text { Standardized } \\
\text { Coefficients }\end{array} \\
\text { Beta } \\
\end{array}$} & \multirow[b]{2}{*}{$\mathrm{T}$} & \multirow[b]{2}{*}{ Sig. } \\
\hline & & $\mathrm{B}$ & Std. Error & & & \\
\hline \multirow[t]{3}{*}{1} & (Constant) & 87.281 & 6.933 & & 12.590 & .000 \\
\hline & PCK & .149 & .054 & .190 & 2.765 & .006 \\
\hline & MPP & .116 & .102 & .111 & 2.154 & .004 \\
\hline
\end{tabular}

a. Dependent Variable: HB

(1) Learning Outcome $=\mathrm{a}+\mathrm{c} \mathrm{PCK}+\mathrm{b} \mathrm{MPP}+\mathrm{e} 2$

$=87,281+0,651 \mathrm{PCK}+0,111 \mathrm{MPP}$

The mediation effect shown by the multiplication of the coefficient ( $a b)$ needs to be tested with the following sober test: the standard error of the indirect effect coefficient (Sat).

$$
\begin{aligned}
\mathrm{Sab} & =\sqrt{b^{2} S a^{2}+a^{2} S a^{2}+S a^{2} S b^{2}} \\
& =\sqrt{0,111^{2} 0,021^{2}+0,651^{2} 0,102^{2}+0,021^{2} 0,102^{2}} \\
& =\sqrt{0,00000543356+0,0044092256+0,000004588} 16 \\
& =0,00441924732
\end{aligned}
$$


Based on the results of the multiplication ab, it can be used to calculate the $t$ statistical effect of mediation with the following formula:

$$
\mathrm{t}=\frac{a b}{S a b}=\frac{0,651 \times 0,111}{0,00441924732}=\frac{0,072261}{0,00441924732}=16,3514270118
$$

Because $t$ count $=16.3514270118$ is greater than $t$ table with a significance level of 0.05 , namely 1.962 , it can be concluded that the mediation coefficient of 0.072261 is significant and means that there is a mediating effect on the quality of the learning process in mediating the Pedagogical Content Knowledge (PCK) relationship with student learning outcomes. The magnitude of the indirect influence of Pedagogical Content Knowledge (PCK) on student learning outcomes mediated by the quality of the learning process is 0.762 or $58.06 \%$. Based on the analysis above, it can be concluded that the quality variable of learning process can mediate Pedagogical Content Knowledge (PCK) and student learning outcomes with perfect mediation. This is because the influence of Pedagogical Content Knowledge (PCK) on student learning outcomes becomes insignificant after inputting the quality of the learning process into the regression equation.

Other factors that affect learning outcomes that are not examined in this study, these factors are 1) internal factors are factors that exist in individuals including (a) physiological factors (health factors, and disabilities) and (b) psychological factors ( intelligence, attention, interest, talent, motivation, maturity, cognitive abilities and readiness) 2) external factors are factors that exist outside the individual, including environmental factors (a) family factors (the way parents educate, relationships between family members, home atmosphere, the economic condition of the family and the understanding of parents), and (b) community factors (student activities in society, mass media, friends, and forms of community life). Furthermore, the instrumental factors (a) school factors (teaching methods, curriculum, teachers, student relations, school discipline, learning tools, school time, standard lessons above the size, the state of the building, learning methods and homework). [3]- [7].

In this case, the PCK competence of teachers can provide quality learning that can support teacher performance to carry out the learning process well, so that the learning outcomes achieved by students, especially in economic subjects, are good. Good PCK teacher competence can make it easier for students to achieve the goals of economic subjects. The objectives of economic subjects according to the Ministry of National Education $(2006$, p. 1) are that students have the following abilities:

a. Understand a number of economic concepts to link economic events and problems in everyday life, especially those that occur in individuals, households, communities and countries.

b. Showing a curious attitude towards a number of economic concepts needed to explore economics

c. Forming a wise, rational and responsible attitude by having knowledge and skills in economics, management and accounting that are beneficial to oneself, household, society and the country

d. Make responsible decisions about social values.

This is in accordance with the opinion of Carl Rogers who argues that educational practice focuses on the teaching aspect. He emphasized that teacher professionalism is needed to support improvements in the achievement of learning outcomes. The PCK ability of teachers has a positive influence on the learning process and student learning outcomes. This is also in accordance with the research conducted by [8] where the results show that the pedagogical competence and professional competence of teachers at SMK (Vocational School) in Tabanan Regency have an effect on the quality of the learning process of certified teachers at SMK (Vocational School) in Tabanan Regency. 
Based on the description above, the PCK ability of teachers is a factor that can affect student learning outcomes. If all the PCK factors of the teacher are strong and have positive values, then the effect will be significant on student learning outcomes, and vice versa. The relatively small influence of the PCK competence of teachers on student learning outcomes shows that the PCK competence of the Economics teachers of SMAN in Tasikmalaya City is still in the medium category. This can be seen from the average score of PCK competency for SMAN economics teachers in Tasikmalaya City of 3.29 out of a maximum score of 5 . The PCK competency of teachers is not good because it is suspected that teachers have not been able to develop explanations for learning materials that are taught creatively, which is an indicator of teacher PCK competence with lowest score. The lack of ability in developing this learning material according to the author makes the implementation of learning less meaningful and less supportive of student learning outcomes. This is the reason why the PCK competency of teachers only has a small effect on student learning outcomes.

\section{Conclusion}

The results of this study indicate that the PCK competency level of teachers consisting of Pedagogical Knowledge and Content Knowledge is in the medium category, meaning that the economics teachers at SMAN in Tasikmalaya City have not mastered the PCK competencies of teachers optimally. The quality of the learning process that is reflected and shaped by indicators of learning organization, learning delivery strategies, student activeness in learning activities and teacher interaction with students, and learning management is in the high category, meaning that it is said that the economics teacher at SMAN in Tasikmalaya City is able to carry out the learning process effectively. Student learning outcomes in cognitive form are included in the high category, meaning that class XI IPS students in Economics have a good average value of learning outcomes. The PCK competency level of the teacher has a positive effect on student learning outcomes, meaning that the higher the PCK competency level of the teacher, the higher the level of student learning outcomes. The quality of the learning process mediates the influence of economic teachers' Pedagogical Content Knowledge (PCK) on student learning outcomes, meaning that the quality of the learning process affects the level of influence of Pedagogical Content Knowledge (PCK) on student learning outcome.

The Writer suggests for schools and related institutions can facilitate teachers in improving competence. The headmaster as the leader can further encourage teachers to continue their studies to increase their competence at work, motivate teachers in scientific development that follows the times, provide opportunities for teachers to take part in trainings and equip facilities that can help to improve teacher competence.

\section{References}

[1] Lembaga survei United Nations Development Programme (UNDP). 2013. Diakses pada 23 Januari 2016. 
[2] Sudjana, N. Penilaian Hasil Proses Belajar Mengajar. Bandung: Rosdakarya, 2008.

[3] Djamarah. Psikologi Belajar. Jakarta: Rineka Cipta, 2011.

[4] Kinanti, G.H. Pengaruh Pengetahuan Awal dan Iklim Sekolah Terhadap Gaya Belajar Siswa dan Implikasinua Terhadap Hasil Belajar Siswa Mata Pelajaran Ekonomi. Tesis. Bandung: Pascasarjana UPI, 2013.

[5] Hamalik. Pendidikan Guru, Berdasarkan Pendekatan Kompetensi.. Jakarta: Bumi Aksara, 2003.

[6] Iim, W. Mengangkat Citra Guru Melalui Penguasaan Kompetensi. Mimbar Pendidikan, 2006.

[7] Purwanto, N. Prinsip-Prinsip dan Tekhnik Evaluasi Pengajaran. Bandung: PT. Remaja Rosdakarya, 2010.

[8] Aryanta, I Gede Putu Agustina. Pengaruh Kompetensi Pedagogik dan Kompetensi Profesional Terhadap Mutu Proses Pembelajaran (studi terhadap guru SMK di kabupaten Tabanan. Tesis. Bandung: Pasca sarjana UPI, 2012.

[9] Debra L.S. The Impact of teacher subject knowledge on learner performance in south Africa: A Within-pupil across-subject approach. University of Stellenbosch, South Afrika: JEL Code:C31, 121, 2013.

[10] Depdiknas. Standar kompetensi Pembelajaran Ekonomi. Jakarta: Departemen Pendidikan Nasional,2006.

[11] Evens, M., Elen, J., \& Depaepe, F. Developing Pedagogical Content Knowledge : Lessons Learned from Intervention Studies, 2015(1).

[12] Shulman, L.S. Those who Understand: Knowledge Growth in Teaching. American Educational Research Association: Vol 15, No. 2 (Feb 1986), PP. 4-14, 1986.

[13] Shulman, L.S. (1987). Knowledge and Teaching: Foundation of the new reform. Harvard Educational Review. Vol. 57. No. 1. February 1987.

[14] Sudjana, N. Penilaian Hasil Proses Belajar Mengajar. Bandung: Rosdakarya, 2011.

[15] Zubaedi. (2011). Desain Pendidikan Karakter: Konsepsi dan Aplikasinya dalam Lembaga Pendidikan. Jakarta: Kencana. 